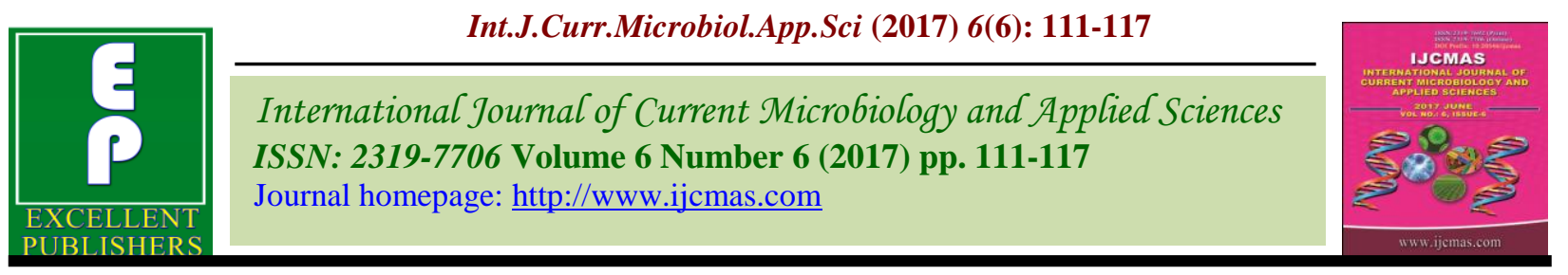

Original Research Article https://doi.org/10.20546/ijcmas.2017.606.013

\title{
Impact Assessment of Cauliflower Variety Sabour agrim in Saharanpur (UP), India
}

\author{
B.P. Shahi ${ }^{1}$, A.K. Mall ${ }^{2 *}$, D.K. Tiwari ${ }^{3}$, V. Singh ${ }^{4}$ and U.S. Gautam ${ }^{5}$ \\ ${ }^{1}$ Krishi Vigyan Kendra, Bharsar-247 001, Saharanpur (U.P.), India \\ ${ }^{2}$ ICAR-Indian Institute of Sugarcane Research, Lucknow-226 002 (UP), India \\ ${ }^{3}$ Krishi Vigyan Kendra, Unnao-229 881 (UP), India \\ ${ }^{4}$ Seed Production Center, Sargatia-274 406, Kushinagar (UP), India \\ ${ }^{5}$ ICAR-Agricultural Technology Application Research Institute, Kanpur, India \\ *Corresponding author
}

\section{A B S T R A C T}

\begin{tabular}{|c|}
\hline Keywords \\
\hline $\begin{array}{l}\text { Early cauliflower, } \\
\text { Curd length, } \\
\text { Curd diameter, } \\
\text { Marketable curd } \\
\text { weight, } \\
\text { Yield, } \\
\text { B:C ratio. }\end{array}$ \\
\hline Article Info \\
\hline $\begin{array}{l}\text { Accepted: } \\
\text { 04 May } 2017 \\
\text { Available Online: } \\
\text { 10 June } 2017\end{array}$ \\
\hline
\end{tabular}

A field experiment was conducted for four consecutive years with a view to assess the response of early cauliflower variety (Sabour agrim) based on multilocational trials in Saharanpur district during the kharif season. The trials were conducted in different locations in entire district and compared with the farmer practice (local). The results revealed that transplanting of early cauliflower variety (Sabour agrim) had a significant effect on growth and yield of cauliflower followed by maximum plant height $(68.4 \mathrm{~cm})$, the best marketable size of curd $(472.9 \mathrm{~g})$, maximum curd length $(15.2 \mathrm{~cm})$, diameter of curd $(17.3 \mathrm{~cm})$ and the maximum yield $(208 \mathrm{q} / \mathrm{ha})$ over local hybrid varieties. Cauliflower can be grown better at places which are cool, frost and litter free than other Brassicaceae. It is difficult to grow cauliflower as a spring crop because it tends to bolt during the condition of extreme heat. Farmers of Saharanpur district mainly grow hybrid varieties of cauliflower for good remuneration. They invest more money on seed due to which cost of cultivation become very high in comparison to return. With the adoption of early cauliflower variety farmers are getting high income over local varieties.

\section{Introduction}

Cauliflower (Brassica oleracea var. botrytis) belongs to family Brassicaceae and is popular for its white tender head or curd. Cauliflower is one of the most important winter flower vegetables of India. India produces $8.57 \mathrm{mt}$ of Cauliflower per year from $4.33 \mathrm{M}$ ha area with an average productivity of about 19.8 $\mathrm{mt} / \mathrm{ha}$ (Anonymous, 2011). The major cauliflower producing states are Bihar, Uttar Pradesh, Orissa, West Bengal, Assam, Haryana and Maharashtra. In the plains, it is available in the market from September to May. It is consumed as a vegetable in curries, soups and pickles. Timing of curd initiation is a key determinant of yield and maturity which is totally influenced by date of transplanting (Muhammad Din et al., 007). Vegetative growth parameters like plant height, number of leaves, whole plant weight, marketable curd weight and yield were influenced significantly by the type of varieties and date of planting reported by Ara et al., (2009). 
Cauliflower thrives best in a cool moist climate. It does not withstand very low temperature or too much heat. The optimum temperature for curd development in cauliflower is 10 to $15^{\circ} \mathrm{C}$. Cauliflower cultivation in Saharanpur district during summer is adversely affected by high temperature. Under such situation, existing cauliflower varieties need to be replaced by suitable high yielding variety which is tolerant to high temperature. Hence, planting with the appropriate time using the suitable variety is essential to ensure a healthy crop and to get good curd yield with high market value. According to Gill and Sharma (1996), sowing times depend on the varieties and the agro climatic conditions prevailing in a particular region. In North-Indian plains, early cauliflower is sown from May end to midJuly, mid-season varieties from July to August end and snowball types from September to October. Therefore, present investigation was carried out to evaluate the performance and adoption of early cauliflower variety "Sabour agrim" by farming community, planted on different locations during kharif season in Saharanpur district of Uttar Pradesh.

\section{Materials and Methods}

A field experiment was conducted during the Kharif season, 2012-13, 2013-14, 2014-15 and 2015-16 at the farmers' fields in deferent locations to evaluate the growth, yield and economical parameters of cauliflower var. "Sabour agrim". The experiment was laid out based on multi-location trials in entire district involving two treatments. The treatment involved early cauliflower variety "Sabour agrim" and Farmers' practice (do not cultivate early cauliflower in this period). The plot size was kept $50 \mathrm{~m} \times 20 \mathrm{~m}$ per treatments. The seeds were collected from Department of Horticulture Bihar Agricultural University, Sabour, Bhagalpur (Bihar). Seeds were sown in the nursery beds at 15 July every year. For early season crop, the seeds were treated with copper oxychloride (2.5 g/lit) mercurial fungicide to save the young seedlings from damping off. Seeds were sown in the month of June for early season crop @ 400 g/ha. The seeds were sown and covered with fine and well-rotten farm yard manure (FYM). Beds were immediately misted with the help of sprinkler and all the beds were covered with wheat straw. After three days, germination of seeds started and completed within six days. Irrigation was given at intervals of three days with the help of sprinkler. When the seedlings attained the height of $3 \mathrm{~cm}$, thinning was done to get healthy and strong seedlings. After thirty days, transplantation of the seedlings was carried out in the evening time. Plant to plant spacing was kept $45 \mathrm{~cm}$ and row to row spacing was $60 \mathrm{~cm}$. Healthy seedlings of uniform size were selected for the transplantation. Nursery beds were irrigated before uprooting of seedlings so that the seedlings could be easily taken out from the beds without any damage to the roots. The soil samples has collected and tested from each experimental plot. Full dose of $\mathrm{P}_{2} \mathrm{O}_{5}(90$ $\mathrm{kg} / \mathrm{ha}$ ) as single super phosphate (DAP) and $\mathrm{K}_{2} \mathrm{O}(60 \mathrm{~kg} / \mathrm{ha})$ as Muriate of potash (MOP) with half dose of $\mathrm{N}(60 \mathrm{~kg} / \mathrm{ha})$ through urea was applied at the time of soil preparation with broadcast method, while the remaining $\mathrm{N}$ was applied as urea 30 days after transplanting. Before transplantation, the experimental field was irrigated and the second irrigation was applied 3- days after transplantation. After this, irrigation was given at 4-6 days interval up to the harvest of crop. Cauliflower was ready to harvest in approximately 60-80 days after transplanting. As soon as the compact head was formed and blanched, it was cut off with the help of a sharp knife, along with the leaves for its protection. Harvesting was done when the curds were still smooth. For the determination of total fresh plant weight, marketable curd 
weight and curd diameter, five randomly plants in each treatment were selected. Curd diameter was obtained with the help of the following formula.

Diameter $=$ circumference/ 3.14.

Plant height was recorded at the time of harvesting of curd. $\mathrm{B}: \mathrm{C}$ ratio was computed by dividing the gross income by cost of cultivation.

\section{Results and Discussion}

\section{Plant height}

The plant height of Cauliflower varied from $48.3 \mathrm{~cm}$ to $68.4 \mathrm{~cm}$. The perusal of data (Table 3) revealed that plant height was maximum $(68.4 \mathrm{~cm})$ during the year of 2015 16 in case of variety "Sabour agrim" and minimum plant height was observed with farmer practice during all the years. It was also found that "Sabour agrim" variety showed highly significant effect on plant height. Maximum plant height with new variety might be attributed to the prevailing conducive climatic conditions which were in conformity with the findings of Ara et al., (2009). Reduced plant height with respect to local variety was observed during all the experimental year. Positive response of variety on the plant height of cauliflower was also noted by Srivastava et al., (2002) and Bing Liang et al., (2005).

\section{Curd length}

The curd length of cauliflower varied from $13.4 \mathrm{~cm}$ to $15.2 \mathrm{~cm}$ during all the years with the variety "Sabour agrim". It was found that curd length of Cauliflower was maximum $(15.2 \mathrm{~cm})$ during the 2015-16 with the transplanting of variety "Sabour agrim". It was also found that this variety showed highly significant effect on curd length than other local varieties of cauliflower. The results related to curd length were in agreement with those reported by Srivastava et al., (2002).

\section{Curd diameter}

It was observed that curd diameter varied between $15.2 \mathrm{~cm}$ to $17.3 \mathrm{~cm}$ with new variety and this was higher over local varieties. Maximum curd diameter $(17.3 \mathrm{~cm})$ was observed in the variety "Sabour agrim" whereas minimum $(14.3 \mathrm{~cm})$ in the local variety in the year of 2015-16. It was also found that curd diameter in the variety "Sabour agrim" was superior to other local variety (Table 2). Maximum curd diameter may be due to genetic ability to grow well in higher temperature and climatic conditions as heaviest curd weight was found in early cauliflower variety "Sabour agrim".

Table.1 Soil status of the different experimental plots

\begin{tabular}{|c|c|c|c|c|c|c|c|}
\hline Years & \multirow{2}{*}{$\begin{array}{c}\text { Number of Multi } \\
\text { location Trials }\end{array}$} & PH & EC & \multirow{2}{*}{\begin{tabular}{l} 
OC \\
\cline { 5 - 7 }
\end{tabular}} & & & \multicolumn{3}{|c|}{ Kg ha } & K \\
\hline $2012-13$ & 15 & 6.5 & 0.27 & 0.57 & 244.5 & 14.3 & 156.2 \\
\hline $2013-14$ & 16 & 6.8 & 0.22 & 0.52 & 267.9 & 16.8 & 138.0 \\
\hline $2014-15$ & 15 & 6.2 & 0.31 & 0.61 & 278.3 & 19.2 & 145.0 \\
\hline $2015-16$ & 20 & 7.1 & 0.28 & 0.51 & 256.2 & 15.7 & 115.5 \\
\hline
\end{tabular}


Table.2 Plant height, curd length, curd diameter, marketable curd weight and marketable curd yields as influenced by early cauliflower var. Sabour agrim (pooled data of multi-location trials)

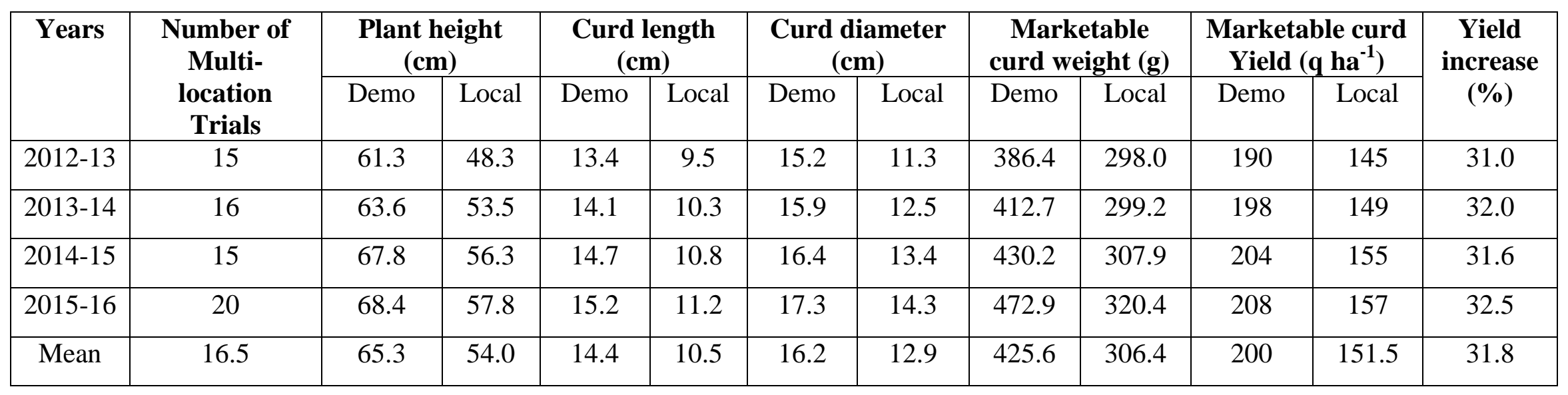

Table.3 Economics as influenced by early cauliflower var. Sabour agrim (pooled data of multi-location trials)

\begin{tabular}{|c|c|c|c|c|c|c|c|c|c|}
\hline Years & \multirow{2}{*}{$\begin{array}{c}\text { Number of multi- } \\
\text { location Trials }\end{array}$} & \multicolumn{2}{|c|}{$\begin{array}{c}\text { Cost of } \\
\text { Cultivation (Rs) }\end{array}$} & \multicolumn{2}{|c|}{ Gross Returns(Rs) } & \multicolumn{2}{|c|}{ B: C Ratio } \\
\cline { 3 - 9 } & & Demo. & Local & Demo. & Local & Demo. & Local & Demo. & Local \\
\hline $2012-13$ & 15 & 54200 & 56000 & 323000 & 217500 & 268800 & 161500 & 4.95 & 2.88 \\
\hline $2013-14$ & 16 & 53950 & 55250 & 336600 & 223500 & 282650 & 168250 & 5.23 & 3.04 \\
\hline $2014-15$ & 15 & 53850 & 55550 & 346800 & 232500 & 292950 & 176950 & 5.44 & 3.16 \\
\hline $2015-16$ & 20 & 52000 & 54350 & 353600 & 235500 & 301600 & 181150 & 5.80 & 3.33 \\
\hline Mean & 16.5 & 53500 & 55287.5 & 340000 & 227250 & 286500 & 171962.5 & 5.36 & 3.10 \\
\hline
\end{tabular}


Fig.1 Horizontal Spread of technology with new interventions done by KVK

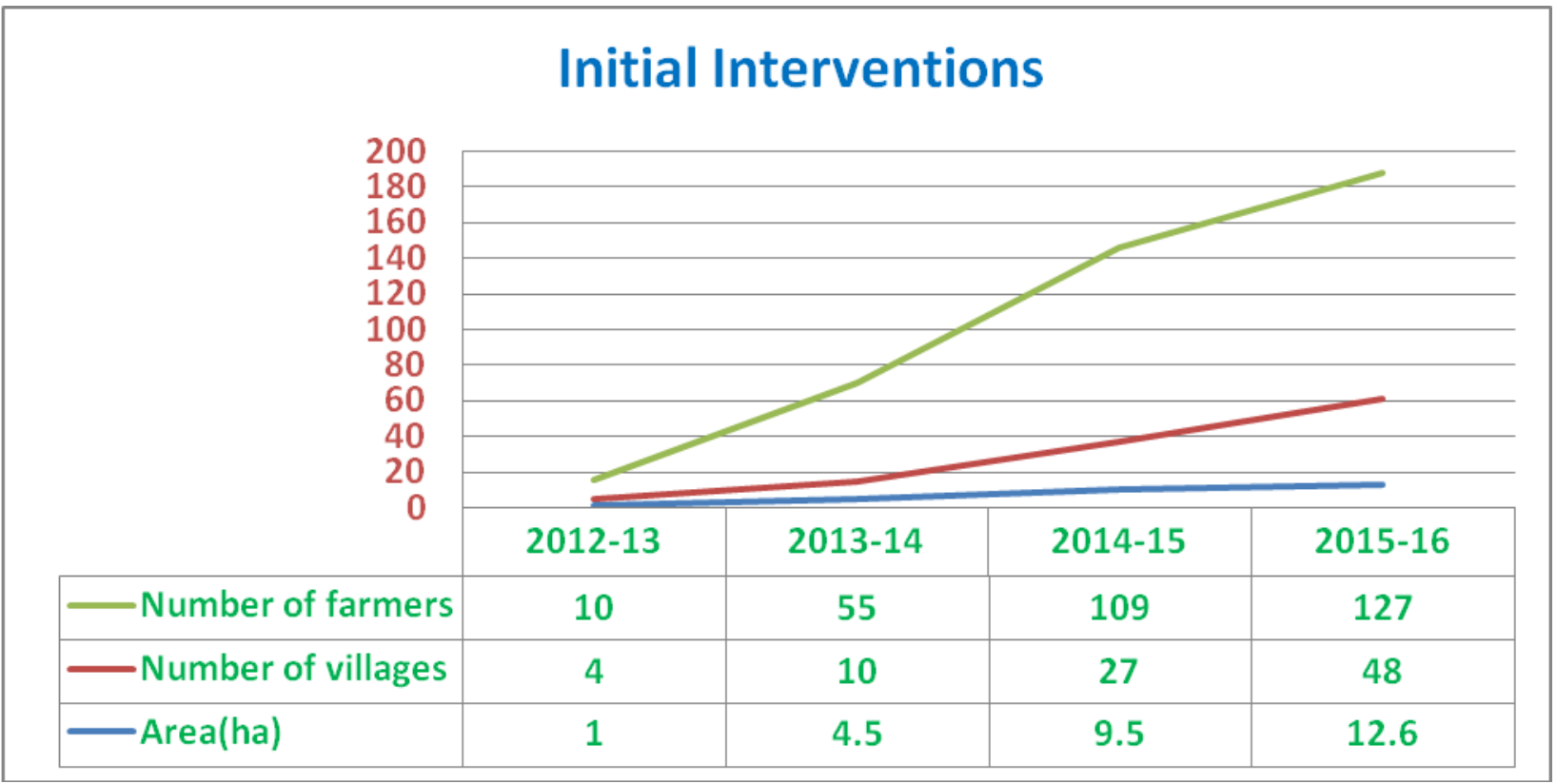

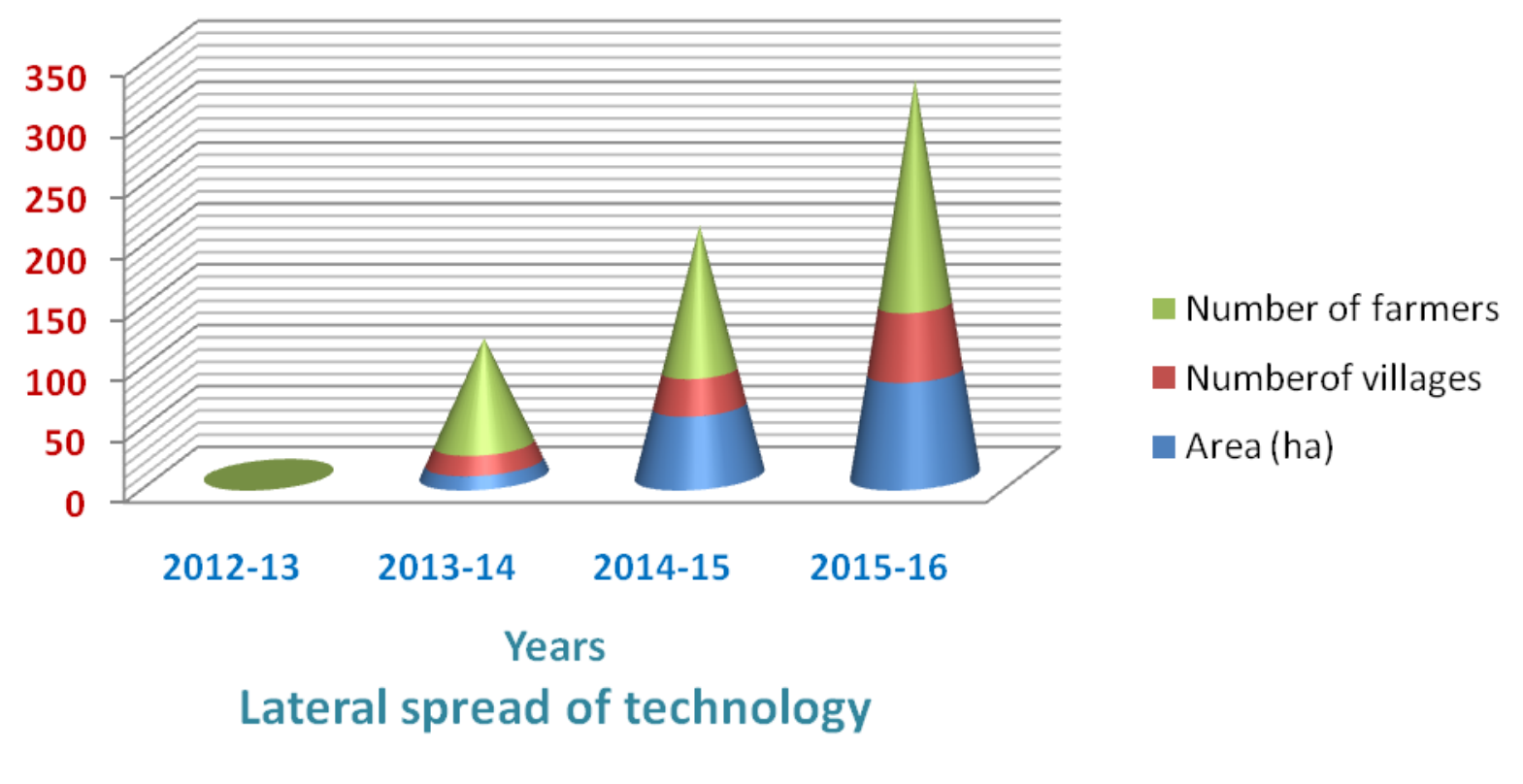




\section{Marketable curd weight}

Maximum marketable curd weight (472.9 g) was observed in the early cauliflower variety "Sabour agrim" during the year 2015-16 whereas minimum $(298.0 \mathrm{~g})$ with the local variety. It was also found that marketable curd weight in the adopted technology (Sabour agrim) proved significantly superior to other local variety. Marketable curd was significantly affected by the variety in which early cauliflower variety recorded large sized leaves and more days to curd maturity resulting in compact white curds with maximum weight. In the present study, curd weight decreased with local variety in all the years which was in agreement with the observations made by many workers (Jana and Mukhopadhyay, 2006; Ajithkumar and Savani, 2007).

\section{Marketable curd yield}

Maximum yield of the marketable curd (208.0 $\mathrm{q} / \mathrm{ha}$ ) was observed planting of early cauliflower variety "Sabour agrim" whereas minimum (157.0 q/ha) with local variety. The data (Table 2) showed that new variety proved significantly superior to other local variety. The data raveled that variety "Sabour agrim" had nearly 30 percent higher curd yield over local variety. Plants transplanted with "Sabour agrim" variety had vigorous growth of leaves with more photosynthetic ability and it also has maximum translocation of energy to the reproductive part of plant so that it has higher curd yield over other local varieties of cauliflower. The results related to curd yield were in agreement with Srivastava et al., (2002).

\section{Economics}

Data on economics presented Table 3 revealed that demonstrated technology of improved early cauliflower variety "Sabour agrim" and their associated agronomical practices produced 66 per cent higher net return (Rs. 286500/-) over the existing farmer practices (Rs. 171962/-). For motivating the farmers acceptance of improved early cauliflower variety "Sabour agrim" the Front line Demonstrations were carried out on the farmer's field and data also indicated that 31.8 per cent higher yield was recorded in demonstrated field than the existing technologies adopted by the farmers.

In conclusion, transplanting of cauliflower with early variety "Sabour agrim" all the years resulted in the maximum yield of good quality marketable curds proved to be the most suitable variety of the early cauliflower var. "Sabour agrim" in the region of Saharanpur district of Uttar Pradesh. Farmers can gain a handsome profit by growing "Sabour agrim" adopting the transplantation and agronomic practices. The potentials of the improved cauliflower verity for higher yield and income were communicated to the farmers through demonstrations. Concerted efforts must be made for promotion of such varieties of the benefit of the farmers. With the efforts made by KVK, many farmers has adopted new technology and this is acceptable by the farming community in the Saharanpur district of Uttar Pradesh and verity has lateral spread in 85 ha area.

\section{References}

Ajith kumar B. and Savani, M.B. 2007. Phasic development model for Cauliflower (Brassica oleracea var. botrytis) using thermal indices. $\mathrm{J}$ Agromet 9 (2): 231-235.

Anonymous. 2011. Annual Report 2011-12, Department of Agriculture and Cooperation, Ministry of Agriculture, Government of India.

Ara N., Kaisar, M.O., Khalequzzman, K.M., Kohinoor, H. and Ahamed, K.U. 2009. 
Effect of different dates of planting and lines on the growth, yield and yield contributing characteristics of Cauliflower. J Soil Nat 3(1): 16-19.

BingLiang, W., Min, X, and JiaShu, C. 2005. Effect of seeding date and cultivars on plant growth and abnormal curd in early Cauliflower. Chin Veg 5: 13-15.

FAO. 2011. Crop Prospects and Food Situation. Global Information and Early Warning System, Trade and Markets Division, FAO, Rome.

Gill, H.S. and Sharma, S.R. 1996. Cole crops. In: Paroda, R. S. and Chadha, K. L. (Eds.), 50 Years of Crop Science Research in India. Indian Council of Agricultural Research, New Delhi, pp. 635-645.
Jana, J.C. and Mukhopadhyay, T.P. 2006. Effect of sowing dates and varieties on growth and curd yield of Cauliflower in terai zone of West Bengal. Orissa J Hort 34(1): 45-48.

Muhammad, Din, Muhammad, Qasim, Noor, Elahi Jan and Faridullah. 2007. Response of Different Sowing Dates on the growth and Yield of Cauliflower Sarhad J. Agric., 23 (2):289-292.

Srivastava, P., Srivastava, B.K and Singh, M.P. 2002. Effect of date of planting and growing environment on the plant survival, growth and yield of early Cauliflower in rainy season. Veg Sci 29 (2): $157-160$

\section{How to cite this article:}

Shahi, B.P., A.K. Mall, D.K. Tiwari, V. Singh and U.S. Gautam 2017. Impact Assessment of Cauliflower Variety Sabour agrim in Saharanpur (UP), India. Int.J.Curr.Microbiol.App.Sci. 6(6): 111-117. doi: https://doi.org/10.20546/ijcmas.2017.606.013 